\title{
Inhibition of MicroRNA-21-5p Promotes the Radiation Sensitivity of Non-Sma' Ce Lung Cancer Through HMSH2
}

\author{
Yu Song ${ }^{a} \quad$ Yun Zuo ${ }^{a} \quad$ Xiao-Lan Qian ${ }^{a}$ \\ Lei Song ${ }^{b}$ Li-Ping Peng ${ }^{b}$
}

Zhi-Peng Chen ${ }^{\mathrm{a}}$

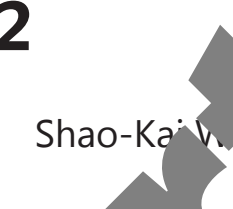

aDepartment of Oncology, Zhangjiagang First People's Hospital, 7 Respiratory Medicine, The First Hospital of Jilin University, Chang

\section{Key Words}

Microrna-21-5p • HMSH2 - Non-small cell lun nce, diation sensitivity

\section{Abstract \\ Background: This study aimed to} on the radiation sensitivity of non-s human MutS homolog 2 (h' who received surgery and $p c$ The patients were assign into On to che effects of microRNA-21-5p (miR-21-5p) -11) $g$ cancer (NSCLC) and the involvement of ative radiotherapy were enrolled in this study. Methods: cells were transfected miR-21-5p mimic, small hMSH2 overexpresing. expression in reaction (qRT $R$ hMSH2 ex for cell reifraso val an

\section{(4)} generate control, Negative control (NC), miR-21-5p inhibitor, rferi hMSH2 (sihMSH2), miR-21-5p inhibitor + sihMSH2 and imunohistochemistry was performed to detect the hMSH2 d and irradiated cells. Quantitative real-time polymerase chain stern blotting were performed to evaluate A549 miR-21-5p and infected and irradiated cells. A colony formation assay was adopted -diph trazolium bromide) assay, and apoptosis was assessed by flow cytometry vure mouse models were established, and tumor volumes and tumor weights were esults: The radiation-sensitive group of patients exhibited lower miR-21-5p but ner hIMSH2 expression than the insensitive group. For irradiated A549 cells, lower cell sur al, higher apoptosis, increased miR-21-5p expression and decreased hMSH2 expression observed at 6 and 8 Gy than at 0, 2 and 4 Gy; compared to $6 \mathrm{~Gy}$, cell survival and hMSH2 expression were decreased and apoptosis and miR-21-5p expression were increased at 8 Gy. Additionally, miR-21-5p was found to target hMSH2. Compared with the control group, the cell survival rate was lower and the apoptosis rate higher in the miR-21-5p inhibitor group, whereas the opposite was observed for the miR-21-5p mimic and sihMSH2 groups. For the mouse model, decreased tumor volume and tumor weight and higher hMSH2 expression were Y. Song and Y. Zuo are contributed equally as co-first authors.

Dr. Yu Song

KARGER
Department of Oncology, Zhangjiagang First People's Hospital,

No.68, Jiyang West Road, Zhangjiagang 215600, Jiangsu Province, (P.R. China)

Tel. +86-15150251773, E-Mail sy5449@163.com 


\section{Cellular Physiology and Biochemistry Published \begin{tabular}{l|l} 
DOI: 10.1159/000481839 & $\begin{array}{l}\text { C } 2017 \text { The Author(s). Published by S. Karger AG, Basel } \\
\text { www.karger.com/cpb }\end{array}$
\end{tabular} \\ Song et al.: Mir-21-5p and Radiation Sensitivity in NSCLC}

found in the miR-21-5p inhibitor, radiation, hMSH2 overexpression, miR-21-5p inhibitor + radiation and $\mathrm{hMSH} 2$ overexpression + radiation groups compared with the control group. In addition, tumor volume and tumor weight were decreased and hMSH2 expression increased in the miR-21-5p inhibitor + radiation and $\mathrm{hMSH} 2$ overexpression + radiation groups compared with the radiation alone group. Conclusion: These findings indicate that inhibition of miR-? can promote the radiation sensitivity of NSCLC by targeting $\mathrm{hMSH}$.

(C) 2017 The Author(s) Published by S. Karger AG, B

\section{Introduction}

Non-small cell lung cancer (NSCLC) comprises the three most common tyr cancer: squamous cell carcinoma (SCC), large cell carcinoma (LCC) and ade Due to its high incidence and mortality, lung cancer has for several decade most frequent malignant cancers worldwide [2]. Approximately $85 \%$ confirmed as NSCLC [3]. Risk factors of NSCLC are smoking (the lead exposure, radon exposure and chronic interstitial pneumonitis [4]. M. of or m tic stage when diagnosed, and the 5-year survival rate is only $16.6 \%$ [5 to rette smoking, a well-known cause of lung cancer, complex interactiol ety netic factors (e.g., rs667282 TT/TC and CC genotypes) and environmental ex (ג robiotics or inhaled exogenous carcinogens) contribute to NSCLC $\%$ The major $t$ peutic methods for NSCLC are surgery, chemotherapy, radiotherapy and $\mathrm{p}$ ive care. $\mathrm{k}$ jtherapy is regarded as a radical primary therapy with non-symptom-driv ontion or as a consolidation therapy after initial chemotherapy, and it is reporter at 'ogically equivalent dose $\geq 53 \mathrm{~Gy}$ halts disease progression. Recently, increasil vide Mas demonstrated the promising outcomes of radiotherapy for selected pants anced NSCLC, with a median overall survival (OS) ranging from 10 to $27 \mathrm{~m}$

MicroRNAs (miRNAs) are an abu nucleotides in their mature $f$ of hundreds of target gene reby modulating a wide range $\rho^{c}$ iono metastasis, apoptosis, a angiog is [9-11]. As an oncomicroRNA involved in tumor progression, microRNA $5 p(p-i R-21-5 p)$ is a potential therapeutic target in lung cancer [12]. Overexpression of $\quad$ has been found in many human malignancies, including NSCLC [13]. F ple, mgh expression of miR-21-5p enhances viability, invasion, viability, and $\mathrm{r}$ or? n NSCLC cell line (NCI-H157), and down-regulation of miR-21-5p significant dect es levels of certain protein in these cells [12]. Although radiation therapy - Iong regarded as a major treatment approach for NSCLC, its effects are l'nited $\mathrm{L}$ ioresistance, as NSCLC cells are often resistant. As one of the primary proteins mish, repair (MMR) system, human MutS homolog 2 (hMSH2) forms heterodimers ther huologs to perform multiple repair processes in response to DNA damage 14]. er, hMSH2 plays a different role in NSCLC, with a function that is associated with king status [15]. Although hMSH2 is a known target gene of the microRNA (miRNA) miR6. een miR-21-5p and hMSH2 with regard to the radiation sensitivity of NSCLC has rarely en reported. Therefore, our study aimed to explore the effect of the targeting of hMSH2 by miR-21-5p on radiation sensitivity in NSCLC.

\section{Materials and Methods}

Study subjects

One hundred fourteen NSCLC patients at stage II or III who were treated with surgery and postoperative radiotherapy at Zhangjiagang First People's Hospital (accumulated radiotherapy dose, 60 Gy; ${ }^{60}$ Co photon 


\section{Cellular Physiology Cell Physiol Biochem 2017;43:1258-1272 \begin{tabular}{l|l|l} 
and Biochemistry Published onlıne: October 09, 2017 & $\begin{array}{l}\text { (c) } 2017 \text { The Author(s). Published by S. Karger AG, Basel } \\
\text { www.karger.com/cpb }\end{array}$ \\
\hline
\end{tabular}}

beam; weekly dose, 10 Gy) from May 2012 to July 2015 were evaluated. The selected patients did not receive any treatment prior to surgery. Radiotherapy sensitivity was assessed according to the OS rate and local or distant recurrence rate; additionally, all of the patients were divided into a sensitive group $(\mathrm{n}=61)$ or an insensitive group $(n=53)$ [17]. Tissue samples from the selected patients were stored in liquid nitrogen until used. Among the included patients, 69 were male and 45 female; the age range was 33-75 years, wi a mean age of 61.7 years. Among the patients, 61 had squamous cell carcinoma and 53 adenocarcinom. 37 had ehigh differentiation, 35 moderate differentiation, and 42 low differentiation; 50 of the patients had lymph node metastasis (LNM) and 64 did not. Regarding surgical procedures, 46 patients were treated y simple lobectomy, 38 with bilateral lung resection and 30 with total lung resection. The studvwas app by the ethics committee of Zhangjiagang First People's Hospital, and all of the patients consent.

\section{Cell culture and radiation regimen}

NSCLC A549 cells were purchased from the cell bank of the Chinese Academy China, and cultured in an incubator at $37^{\circ} \mathrm{C}$ with $5 \% \mathrm{CO}_{2}$ in RPMI 1640 medium USA) containing 10\% fetal bovine serum (Invitrogen Gibco, NY, USA). Cells at 80

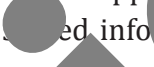
(1) digested and collected for cell suspension $\left(5 \times 10^{4} / \mathrm{ml}\right)$. The cells w 6 -well plates at 2 $\mathrm{mL}$ per well, and all plates were $\gamma$-ray irradiated using the PHOEN Doses were $0 \mathrm{~Gy}, 2 \mathrm{~Gy}, 4 \mathrm{~Gy}, 6$ Gy or $8 \mathrm{~Gy}$, and the medium was chang aily

\section{Quantitative real-time polymerase chain reaction T-PCR)}

Total RNA was extracted from NSCLC tissues, NS sues of pat receiving different radiation doses and cells in each group according to the manufor instructions (QIAGEN, Valencia, CA). The optical density (OD) 260/280 value of the extracte $\mathrm{NA}$ easured using an ultraviolet radiation (UV) spectrophotometer; the concentration was ca ed, ne RNA was stored at $-80^{\circ} \mathrm{C}$. Reverse transcription was carried out according to kit i- EN, Valencia, CA). Primers were designed based on gene sequences in the GenBank $\mathrm{SE}$ uatabases using Primer 5.0; the sequences are shown in Table 1. The designed primers sy esized by Shanghai Sangon Company (Shanghai, China). PCR was carried out in a and included SYBR PremixExTaq $(10 \mu \mathrm{L})$, forward primer $(0.8 \mu \mathrm{L})$, reverse primer ( $\quad$ ROX kurence Dye II $(0.4 \mu \mathrm{L})$, DNA template $(2 \mu \mathrm{L})$, and $\mathrm{dH}_{2} \mathrm{O}(6$ $\mu \mathrm{L})$. The reaction conditions w in, followed by 40 cycles of $95^{\circ} \mathrm{C}$ for $5 \mathrm{~s}, 60^{\circ} \mathrm{C}$ for $30 \mathrm{~s}$, and $72^{\circ} \mathrm{C}$ for $15 \mathrm{~s}$. U6 and $\beta$-acti ere usea internal reference for miR-21-5p and hMSH2, respectively. A dissolution curve was ad to ev luate the reliability of the results. Relative expression of the target gene was calculated using the inflection point in the amplified power curve) according to the $2^{-\Delta \Delta}$ Ct method [18 2.

Cell rotein extracted, and the concentration was assessed using a bicinchoninic acid (BCA) $\mathrm{k}^{\wedge}+$ (Wuho ter Bioengineering Co., Ltd., Wuhan, China) according to the manufacturer's instructions. sacte ins were combined with sample buffer and boiled at $95^{\circ} \mathrm{C}$ for $10 \mathrm{~min}, 30-\mu \mathrm{g}$ proteins in l. The w otein was separated by $10 \%$ sodium dodecyl sulfate-polyacrylamide gel electrophoresis SDS- ahan Boster Bioengineering Co., Ltd., Wuhan, China) at $80 \mathrm{~V}$ to $120 \mathrm{~V}$. The proteins were then transrcred to a polyvinylidene fluoride (PVDF) membrane at $100 \mathrm{mV}$ for 45-70 min. After $1 \mathrm{~h}$ of blockig $5 \%$ bovine serum albumin (BSA) at room temperature, a primary antibody against hMSH2 (1:1000 on; Abcam, Cambridge, England) was incubated overnight at $4^{\circ} \mathrm{C}$. After rinsing 3 times each with Trisaffered saline and Tween (TBST) for $5 \mathrm{~min}$, corresponding secondary antibodies were added, followed by incubation at room temperature for 1 h. The membrane was washed as above, and chemiluminescence reagent and the Bio-Rad Gel Dol EZ

Table 1. Primer sequences for quantitative real-time polymerase chain reaction (qRT-PCR), mir-21-5p, microRNA-21-5p; hMSH2, human MutS homolog 2

\begin{tabular}{lcc}
\hline Gene & Upstream primer $\left(5^{\prime} \sim 3^{\prime}\right)$ & Downstream primer $\left(5^{\prime} \sim 3^{\prime}\right)$ \\
\hline Has-mir-21-5p & ACGTTGTGTAGCTTATCAGACTG & AATGGTTGTTCTCCACACTCTC \\
hMSH2 & AATGACTTGGAAAAGAAGATGC & TTAAAGAAGTCAATTTGCTGTTG \\
$\beta$-actin & CAGAAGGAGATTACTGCTCTGGCT & TACTCCTGCTTGCTGATCCACATC \\
U6 & CTCGGTTCGGCAGCACA & AACGCTTCACGAATTTGCGT \\
\hline
\end{tabular}




\section{Cellular Physiology Cell Physiol Biochem 2017;43:1258-1272 \begin{tabular}{l|l|l} 
and Biochemistry Published online: October 09, 2017 & $\begin{array}{l}\text { C } 2017 \text { The Author(s). Published by S. Karger AG, Basel } \\
\text { www.karger.com/cpb }\end{array}$ \\
\hline
\end{tabular}}

Song et al.: Mir-21-5p and Radiation Sensitivity in NSCLC

imaging instrument (GEL DOC EZ IMAGER, Bio-Rad, California, USA) were utilized for detection. $\beta$-Actin (1:3000 dilution; Becton, Dickinson and Company, USA) was used as an internal reference. The gray-scale values of target bands were analyzed using Image J software.

\section{Colony formation assay}

A549 cells at the logarithmic growth phase were digested with pancreatin to generate single-ce suspensions and then seeded into 6-well plates. The suspensions were divided into 0 Gy, 2 Gy, 4 Gy, 6 Gy and 8 Gy groups, with respective cell numbers of 500, 2, 000, 4, 000, 6, 000, and 10, 000; three par samples were prepared for each group. After adherence, cells were $\gamma$-ray irradiated for $2 \mathrm{~h}$ and incuba $37^{\circ} \mathrm{C}$ with $5 \% \mathrm{CO}_{2}$ for 2 weeks; fresh medium was added as appropriate. After 2 weeks, the was removed, followed by washing with phosphate-buffered saline (PBS), fixation in 75\% me min, and staining in $0.5 \%$ crystal violet staining solution for $20 \mathrm{~min}$. The cells were wa and the number of cells was counted (colonies with more than 50 cells by microsco recorded as a clone). The multi-target single-hit model $[\mathrm{SF}=1-(1-\mathrm{eD} / \mathrm{D} 0) \mathrm{N}]$ in $\mathrm{S} ;$ was used to produce a cell survival curve to obtain the survival fraction (SF) und doses.

\section{Cell transfection}

Sequences for hMSH2 overexpression as well as miR-21-5p in tors ics were synthesized by Shanghai GenePharma Co., Ltd. (Shanghai, China). The sequences ollo s: miR-21-5p inhibitor: 5'-UCAACAUCAGUCUGAUAAGCUA-3'; miR-21-5p mir 5'-AACAUC 'UGAUAAGCUAUU-3'; negative control (NC), 5'-CAGUACUUUUGUGUAGUACAA-3'; hy small int ing RNA (siRNA): forward sequence, 5'-CCACGUUCAUGGCUGAAAUTT-3', revers ${ }^{-}$nce, 5'-AUUUCAGCCAUGAACGUGGTT-3'. Cells were divided into control, miR-21-5p NC, mif -5p tor, miR-21-5p mimic, sihMSH2, miR21-5p inhibitor + sihMSH2 and hMSH2 overexpress roup posome Lipofectamine 2000 was used for transient transfection. One day before trap tion, e digested and seeded into 6-well plates; when the cell density reached 90-95\%,50 or n-free culture medium was used to dilute $1.0 \mu \mathrm{g}$ of each construct and $1 \mu \mathrm{L}$ of Lipofectamine with the diluted construct within nd room temperature for $20 \mathrm{~min}$. After changing the medium, this mixture was added well; truculture plate shaken to mix well, followed by culture in an incubator containing 5\% Cours later, the medium was replaced. After transfection for $12 \mathrm{~h}, \gamma$-ray radiation at differ doses ( 0 , o and $8 \mathrm{~Gy}$, respectively) was carried out. The cells were then continuously cultured for 2 . h befo

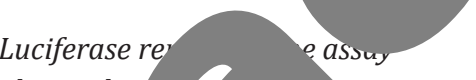

The onlin ni gene prediction tool Targetscan (httn:// www. targetscan. org/) was used $t$ cree ro ones of miR-21 and to predict the binding site of miR-21 and in the 3' untra d re JTR) of hMSH2. Based on the predicted binding site and the human $g^{\wedge}$ nome ce, the hMSH2 3'UTR sequence containing the miR-21 binding site was amplified CR sequences: Forward, 5'CCGCTCGAGATCCCAGTAATGGAATGAAG3'; Reverse, AATGC, rCGCCATCACTTATTATTGCCTATGT3'). After XhoI and NotI digestion, the fragment was pstream of the promoter of the psiCHECK-2 vector (Promega Corporation, USA). The hMSH2 R wru-type (WT) plasmid was constructed and named phMSH2-Wt. Based on this plasmid, a mutated in $r$ was used to induce mutation in the miR-21 binding site to construct the hMSH2 3'UTR mutant (MUT) aid phMSH2-Mut (Primer sequences: Forward, 5'CCGCTCGAGTGAAGGTAATATTGTGAAGCTATTGTC3'; verse, 5'ATAAGAATGCGGCCGCCATCACTTATTATTGCCTATGT3'). Sequencing was performed to confirm successful cloning. A plasmid extraction kit (Promega Corporation, USA) was used to generate four groups: miR-21 mimic + p hMSH2-WT (WT + mimic group), miR-21 mimic + p hMSH2-MT (MT + mimic group), miR$21 \mathrm{NC}+$ p hMSH2-WT (WT + NC group) and miR-21 NC + p hMSH2-MT (MT + NC group). The reporter gene vector used in the experiment was pcDNA3. l-luc (GenePharma company, Shanghai, China), encoding firefly luciferase. To assess the transfection efficiency, pRL-TK, which encodes Renilla luciferase, was used as an internal control. Fluorescent STOP \& Glo Reagent was preheated to establish a zero value for fluorescence measurement. Thereafter, $40 \mu \mathrm{L}$ of LARII and $40 \mu \mathrm{L}$ of STOP \& Glo Reagent were added to a tube, and fluorescence was measured and recorded using a fluorescence meter.

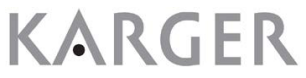




\section{Cellular Physiology Cell Physiol Biochem 2017;43:1258-1272 \begin{tabular}{l|l|l} 
DOI: 10.1159/000481839 & $\begin{array}{l}\text { O 2017 The Author(s). Published by S. Karger AG, Basel } \\
\text { www.karger.com/cpb }\end{array}$ \\
\cline { 2 - 3 }
\end{tabular}}

\section{MTT (3-(4, 5-dimethylthiazol-2-yl)-2, 5-diphenyltetrazolium bromide) assay}

The MTT reagent kit (DOJINDO Company, Japan) was used for detecting cell viability. Cells of the different groups at the logarithmic growth phase were digested with $0.25 \%$ pancreatin and seeded into 96 well plates at a cell density of 5000/cell, with each well containing $100 \mu \mathrm{L}$. After adherence, the cells were $\gamma$-ray irradiated at $0,2,4,6$ and 8 Gy for $2 \mathrm{~h}$ and then cultured for $24 \mathrm{~h}$ before $10 \mu \mathrm{L}$ MTT in medium w added to each well. The culture plate was incubated at $4^{\circ} \mathrm{C}$ for $1-4 \mathrm{~h}$, after which the absorbance at $490 \mathrm{n}$. was detected using a microplate reader (Thermo Fisher Scientific, Waltham, USA). Cell survival rate $=$ (OD

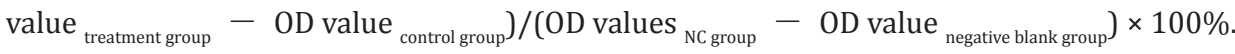

\section{Flow cytometry}

The Annexin V reagent kit (Beyotime Biotechnology, Beijing, China) was utilized for detecti Cells of the different groups were cultured for $12 \mathrm{~h}, \gamma$-ray irradiated at $0,2,4,6$ and 8 for another $48 \mathrm{~h}$. The cell culture medium in the 6-well plate was collected and placed intoc afuge th $d$ then analyzed for cell lysis. The cells were washed with PBS, and $0.25 \%$ pancreatin y's

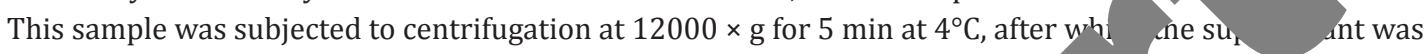
discarded. The pellet was collected, and the cells were prepared as a dense ceh nsion containing 50, 000-100, 000 cells with PBS, followed by centrifugation for another the sup discarded. A 195- $\mu \mathrm{L}$ aliquot of Annexin V-fluorescein isothiocyanate (FITC) w a cell sension, to which $5 \mu \mathrm{L}$ of Annexin V-FITC was added, followed by mixing and incub $n$ in $\quad$ for 10 min at room temperature. After centrifugation for $5 \mathrm{~min}$, the supernatant was co $\quad \mathrm{Ne} \wedge, 190 \mu \mathrm{L}$ of the Annexin V-FITC sample and $10 \mu \mathrm{L}$ of propidium iodide solution re added. Afte ving well, the new mixture was incubated in an ice bath, followed by flow cytometry a (BD FACSC II, USA). Early apoptosis was detected in the lower right quadrant, advanced apoptos. detected in the upper right quadrant, and surviving cells were detected in the lower left quad, The tosis rate = early apoptosis rate + late apoptosis rate.

\section{Mouse model establishment}

This animal experiment was approved committee of Zhangjiagang First People's Hospital. BALB/c male nude mice aged $6 \mathrm{r}+2 \mathrm{~g}$ purchased from Xipuer-Bikai Experimental Animal Co., Ltd. (Shanghai, China used mene experiment and raised under specific pathogen-free (SPF) conditions. After adapti feea. 21-5p inhibitor, hMSH2 ov pression, ation group, miR-21-5p inhibitor + radiation and hMSH2 overexpression + radiation $\quad$ vs. Su' cutaneous injection was performed in the right hind legs, as follows: $100 \mu \mathrm{L}$ of A549 cells for the sup; $1 \times 10^{7}$ cells/ml miR-21-5p inhibitor cells for the miR-21-5p inhibitor and miR hiblum radiation groups; and $1 \times 10^{7}$ cells $/ \mathrm{mL} \mathrm{hMSH2-overexpressing} \mathrm{cells}$ for the hMSH2 + radiation group. Tumor growth was observed. When the tumor volume reached 100 bic $n$, a $\mathrm{n} f$ in the latter two groups were $\gamma$-ray irradiated at a total dose of $32 \mathrm{~Gy}$ (8 Gy/ week). A nier vas used to measure tumor volume. On the $28^{\text {th }}$ day, all of the mice were killed ( $\mathrm{n}$ mice-d for the study died before the end of the experiment), and the tumor tissues were collected ner in histochemical analysis. e antigen repair solution at a pH of 7.2-7.4. The primary anti-hMSH2 antibody (1:1000; Cell Signaling chnology, Inc, Massachusetts, USA) was added, and the tissue samples were incubated overnight at $4^{\circ} \mathrm{C}$. The samples were then incubated for $1 \mathrm{~h}$ at $37^{\circ} \mathrm{C}$ and washed with PBS (0.01 mol/L); a biotin-labeled secondary antibody (Wuhan Boster Bioengineering Co., Ltd., China) was added dropwise. The samples were incubated at $37^{\circ} \mathrm{C}$ for $30 \mathrm{~min}$ and stained for $10 \mathrm{~min}$ with diaminobenzidine (DAB). The cells were then stained with hematoxylin, dehydrated by an alcohol gradient, sealed with neutral balsam and observed under a light microscope. The average optical density was calculated using Image-Pro Plus software for pathological image analysis, and statistical analysis was conducted.

The judgment criteria for the experimental results were that the hMSH2 protein signal was located in the nucleus, and positive staining was displayed as yellow or dark-brown granules. Integration was achieved 
Song et al.: Mir-21-5p and Radiation Sensitivity in NSCLC

in accordance with the percentage of the positive area of the total area [15]: 0 points (0\%), 1 point (1-10\%), 2 points (11-50\%) and 3 points $(>50 \%)$. The staining intensity was scored and stratified as follows: 0 points (negative), 1 point (weakly positive), 2 points (moderate) and 3 points (strong positive). Sum of the integration of staining intensity and range $\geq 4$ was defined as high expression; that $<4$ was defined as low expression.
Table 2. Relationship between radiation sensitivity and clinicopathological characteristics in NSCLC patients in the sensitive and insensitive groups, NSCLC, nonsmall cell lung cancer

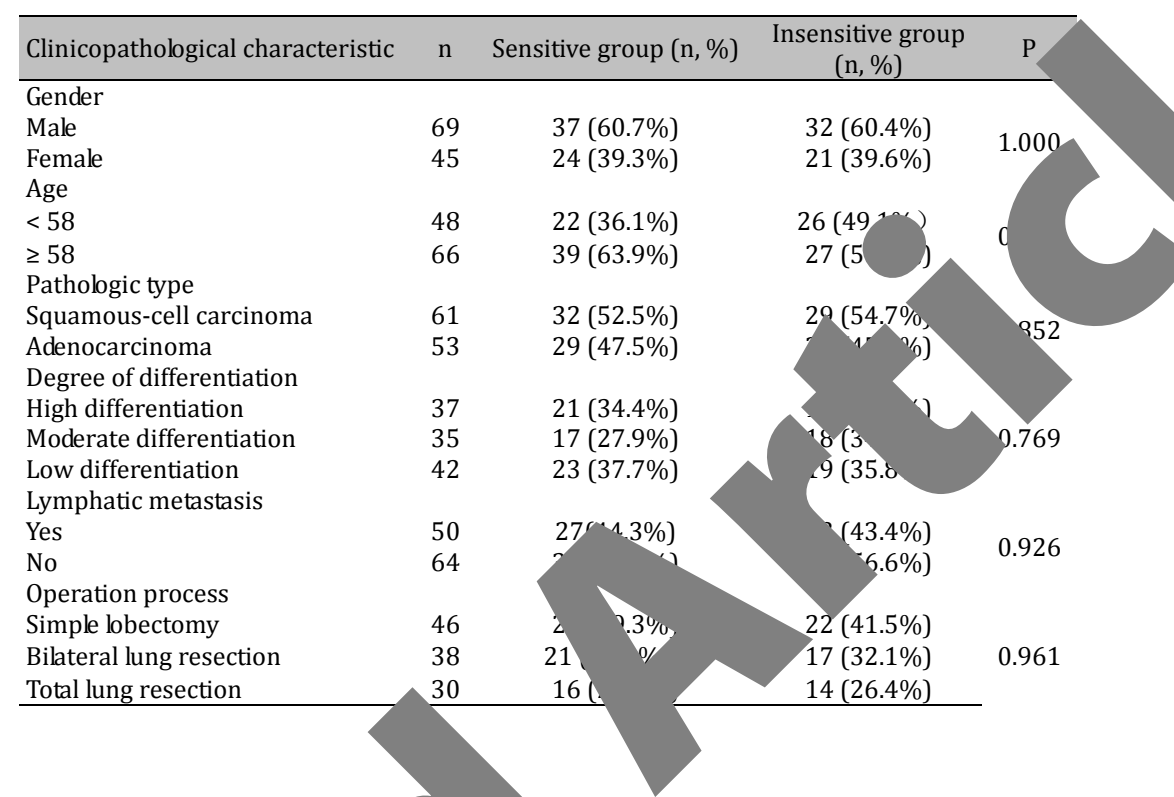

\section{Statistical analysis}

Data were analyzed using Statistical Package measurement data are reported as the mean \pm stanc used for comparison between two groups of m conforming to a normal distribution. One-
way analysis of variance (ANOVA) was use percentage and rate, as analyzed using the t. A value of $P<0.05$ was regarded as statistically significant.

\section{Results}

Relationship betwe "adir sensitivity and clinicopathological characteristics of NSCLC patien

No obvio ation between radiation sensitivity and clinicopathological characteristics, $n$ ge, gender, pathologic type, degree of differentiation, lymphatic metastasis $\mathrm{ds}$ s intervention, was found for the examined NSCLC patients (all $P>$ $0.05)(2$ 2).

thy Sciences (SPSS) version 18.0. The devia (SD). The t-test and paired t-test were conforming to a normal distribution. One(1) ing a. tissue expression of miR-21-5p and hMSH2 between sensitive and insensitive tients

$R$ was used to detect mRNA levels of miR-21-5p and hMSH2 in lung cancer ues. Ine level of miR-21-5p mRNA was significantly decreased $(P<0.05)$ and that of AY" 2 markedly increased $(P<0.05)$ in the sensitive group $(\mathrm{n}=61)$ compared with the sitive group $(\mathrm{n}=53)($ Fig. 1A). Western blotting was used to detect the protein levels hMSH2 in lung cancer tissues. Compared with the insensitive group, the level of hMSH2 protein in the sensitive group was notably increased, and the difference was statistically significant $(P<0.05)$ (Fig. 1B).

Correlation of miR-21-5p and hMSH2 expression levels with radiation sensitivity in A549 cells under different $\gamma$-ray radiation doses

The cell clone formation method was adopted for detecting the sensitivity of A549 cells under different doses of $\gamma$-ray radiation. The A549 cell survival rate gradually decreased with increasing dose. Moreover, the survival rates at 6 and 8 Gy were both significantly 

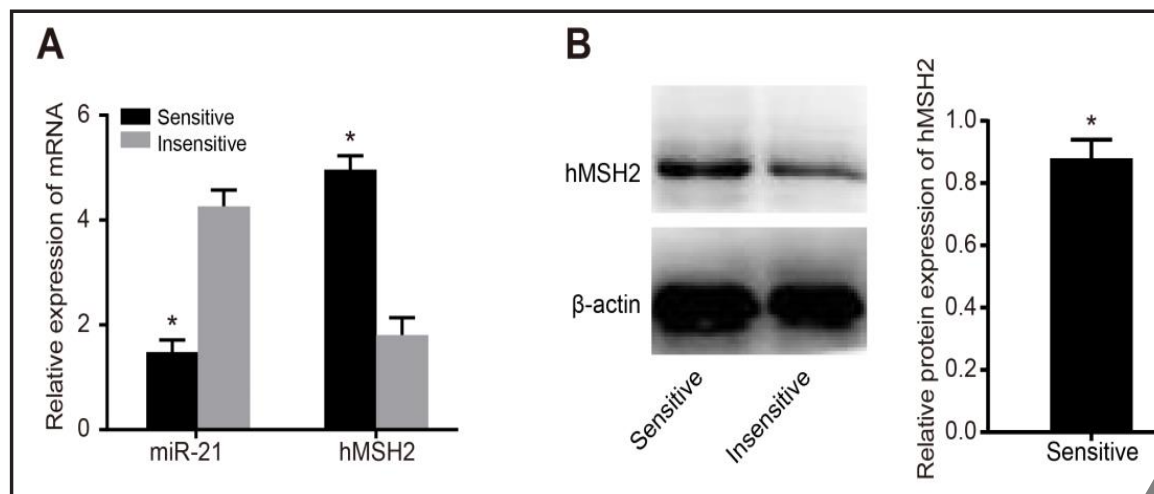

Fig. 1. Expression levels of miR-21-5p and hMSH2 in lung cancer tissues between senc groups. A, mRNA levels of miR-21-5p and hMSH2 mRNA in the sensitive group $(n=61$ ( $\mathrm{n}=53$ ), as detected by qRT-PCR. B, Protein level of hMSH2 between the sensitive detected by western blotting; ${ }^{*}, \mathrm{P}<0.05$, compared with the insensitive oroup. min hMSH2, human DNA MutS homolog 2; qRT-PCR, quantitative real-ti

nsensit_,oups, as

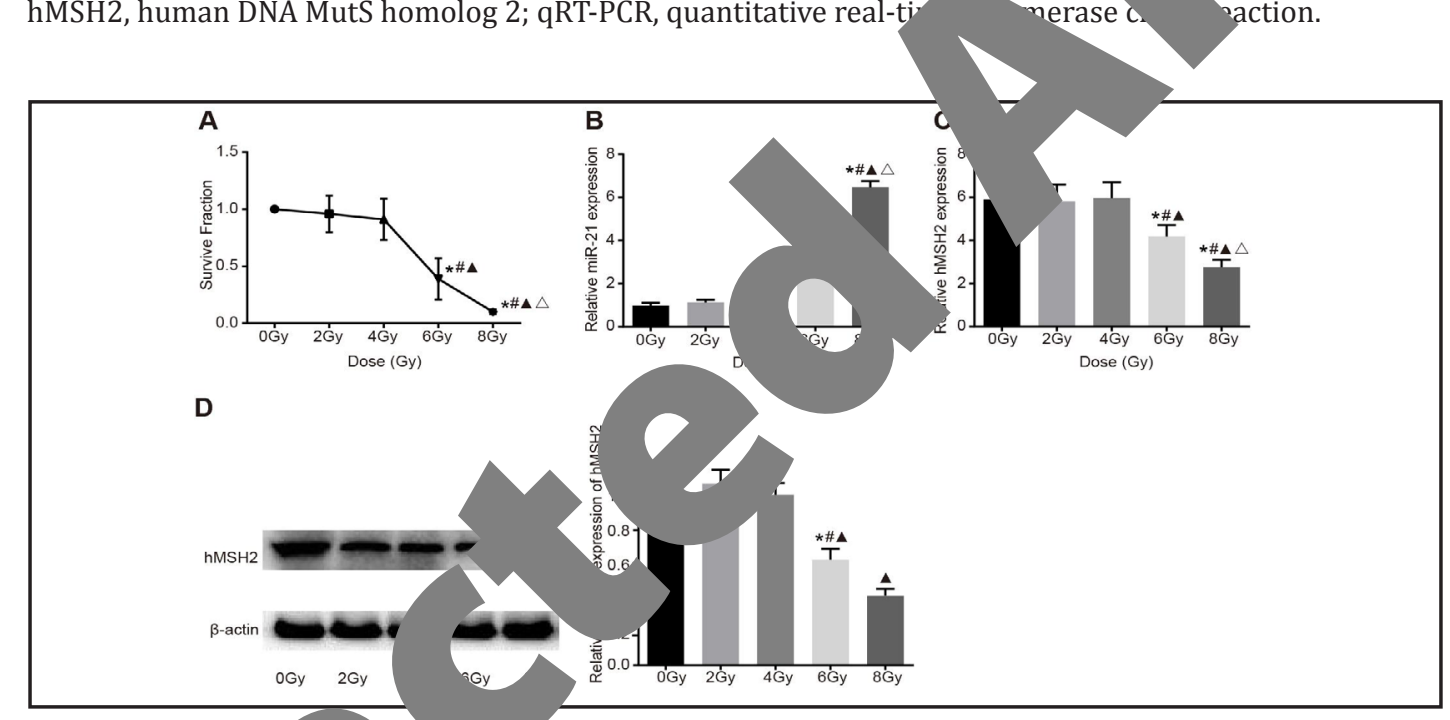

Fig. 2. Relationshi A549 cells unde iff ses of $\gamma$-ray radiation. A. Survival curve of A549 cells based on the colony formation a $\mathrm{V}$. B, atic $\mathrm{p}$ between mRNA level of miR-21-5p and radiation dosage, as detected by qRT-PCR S ration $>$ etween mRNA level of hMSH2 and radiation dosage, as detected by qRT-PCR. D Relatio between protein level of hMSH2 and radiation dosage, as detected by western blotting; *, com ${ }_{1}$ with $0 \mathrm{~Gy}$; \#, $\mathrm{P}<0.05$, compared with 2 Gy; $\Delta, \mathrm{P}<0.05$, compared with 4 Gy; $\Delta, \mathrm{P}<0.05$, d with Gy. miR-21-5p, microRNA-21-5p; hMSH2, human MutS homolog 2; NSCLC, non-small cell lung XT-PCR, quantitative real-time polymerase chain reaction.

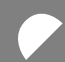

eased compared with those at 0,2 and 4 Gy (all $P<0.05$ ), and the survival rate at 8 ary was markedly decreased compared with that at 6 Gy $(P<0.05)$ (Fig. 2A). The relative expression levels of miR-21-5p and hMSH2 under various doses of $\gamma$-ray irradiation were detected by qRT-PCR and western blotting, with the results showing that the level of miR21-5p mRNA increased and the levels of hMSH2 mRNA and protein both decreased with increasing $\gamma$-ray radiation dose. Compared with $\gamma$-ray radiation at 0,2 and 4 Gy, 6 and 8 Gy resulted in an increased level of miR-21-5p mRNA but decreased levels of hMSH2 mRNA and protein (all $P<0.05$ ). Compared with $\gamma$-ray radiation at 6 Gy, the mRNA level of miR-21-5p was significantly increased but the mRNA and protein levels of hMSH2 markedly decreased at 8 Gy (all $P<0.05$ ) (Fig. 2B, C).

\section{KARGER}


Fig. 3. Relative luciferase activity of hMSH2 3'UTR, miR-21-5p mimic and miR-21 NC. A, B, Two binding sites for miR21-5p are present in the hMSH2 3'UTR. C, Analysis of the relative luciferase activity of hMSH2 3'UTR, miR-21-5p mimic and miR-21-5p NC after co-transfection; **, $\mathrm{P}<0.01$, compared with that before transfection. miR-21-5p, microRNA21-5p; hMSH2, human DNA MutS homolog 2; $\mathrm{NC}$, negative control.

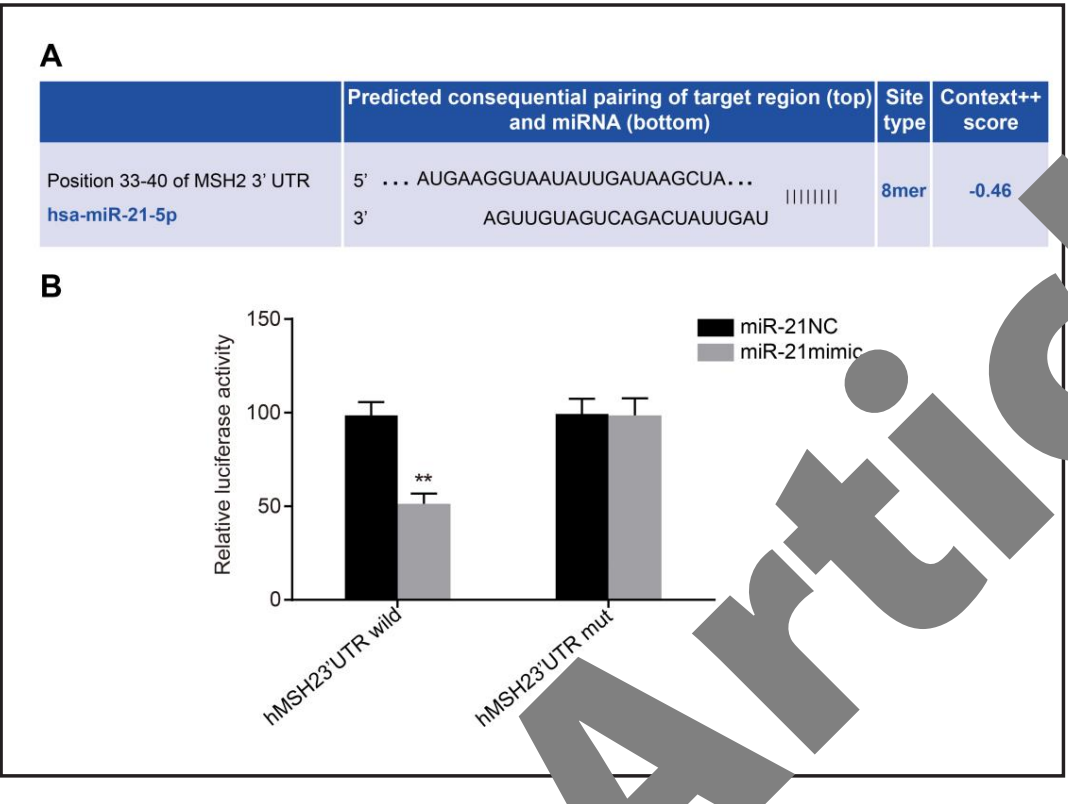

Fig. 4. Cell viability in each group under different doses of $\gamma$-ray radiation, as detected by the MTT assay. miR-21-5p, microRNA-21-5p; hMSH2, human DNA MutS homolog 2.
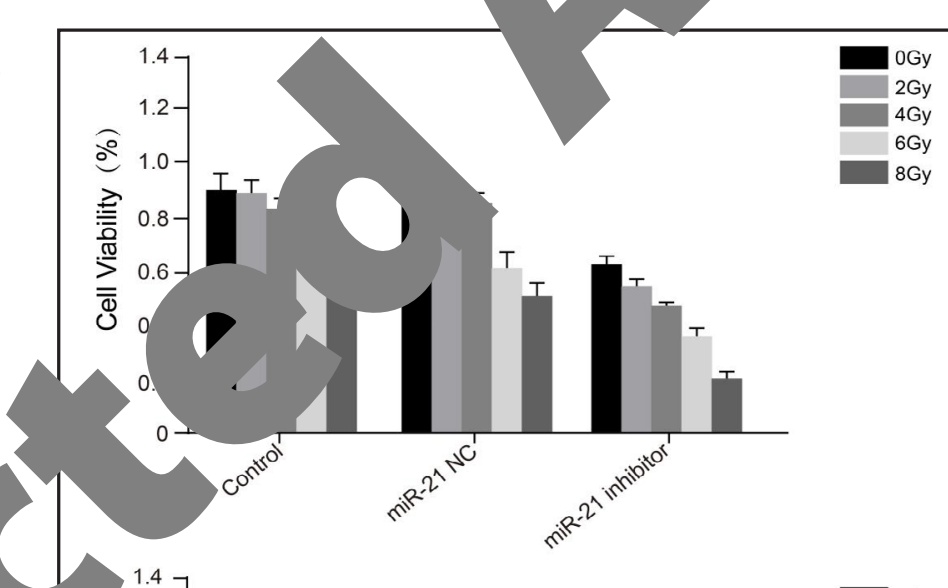
Table 3. Effect of miR-21-5p on cell viability in A549 cells of each group under different doses of $\Gamma$-ray irradiation, *, P $<0.05$, compared with the control group, ${ }^{*}, \mathrm{P}<0.05$, compared with 0 Gy, 2 Gy and 4 Gy, $\mathbf{\Delta}$, $\mathrm{P}<0.05$, compared with 6 Gy; miR-21-5p, microRNA-21-5p; NC, negative control; hMSH2, human MutS homolog 2

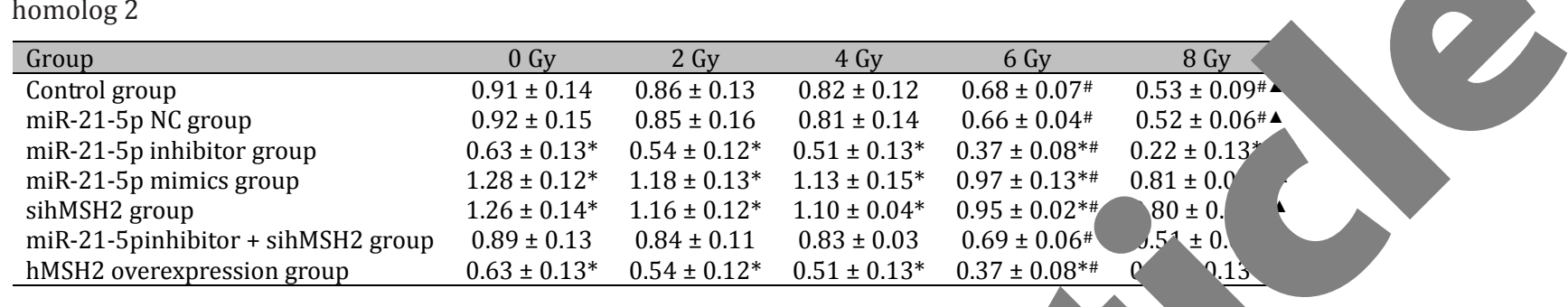
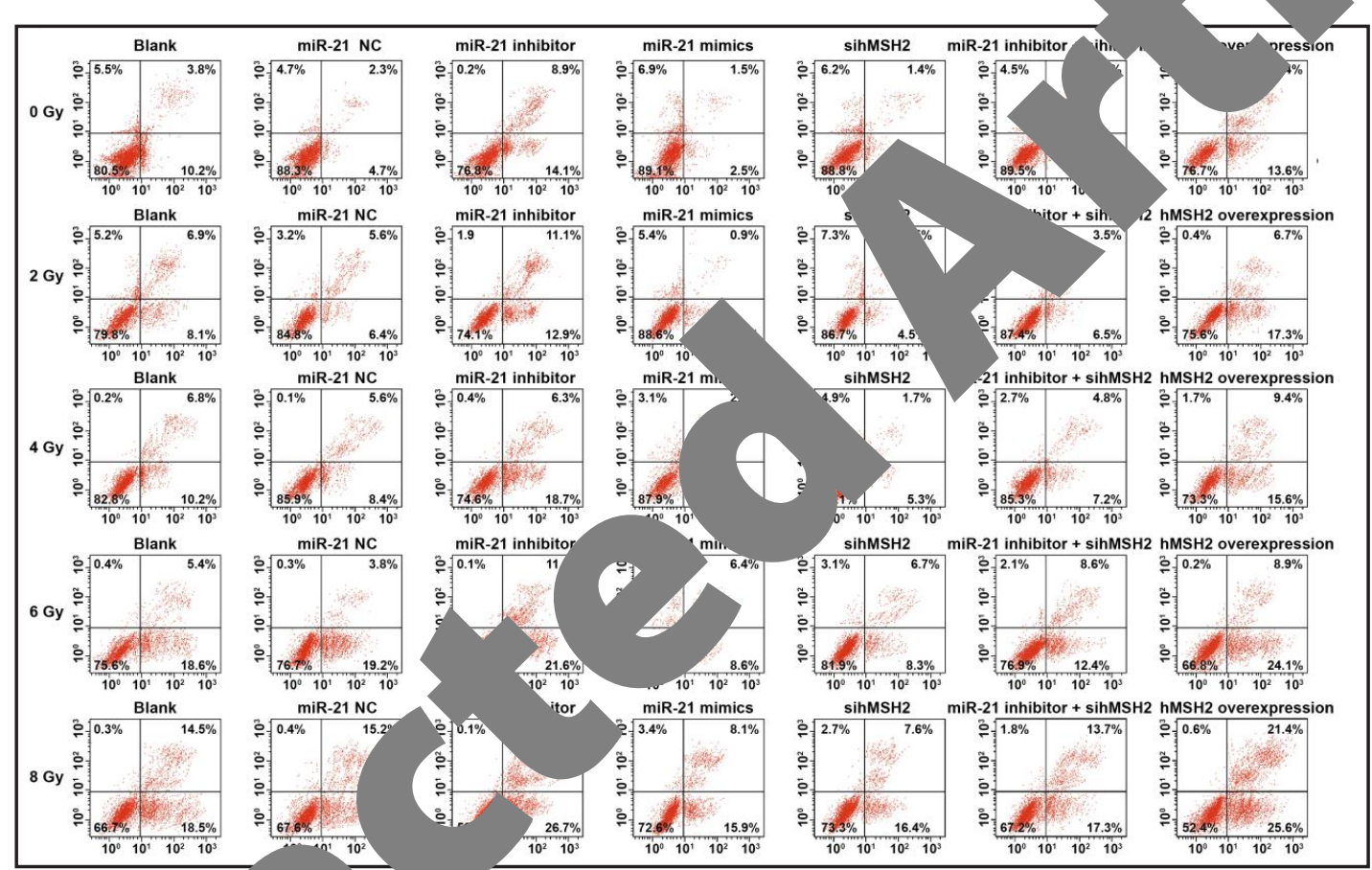

SihMSH2 MiR-21 inhibitor + SihMSH2 hMSH2 overesion
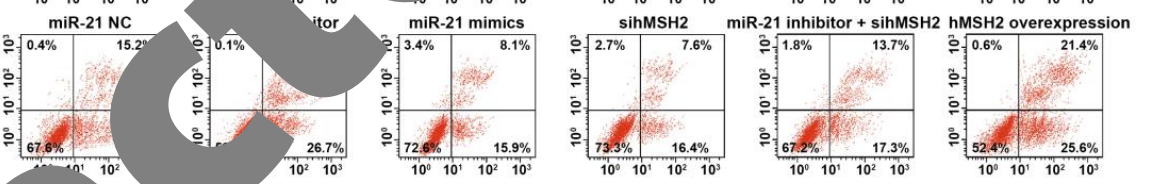

Fig. 5. Cell apopt

activity

roup under different doses of $\gamma$-ray radiation, as detected by flow cytometry.

activity $\quad$ co- $t$ ction of wild-type hMSH23'UTR-WT and miR-21-5p mimic compared vith tha he untransfected miR-21-5p NC group $(P<0.01)$. Changes in relative luciferase -y wo t found with transfection of mutant hMSH2 3'UTR-MUT or miR-21-5p mimic iR-21- NC (Fig. 3C). The results were consistent with the bioinformatic prediction, furt. irming that miR-21-5p can bind to the seed region in the hMSH2 mRNA 3'-UTR.

\section{miR-21-5p promotes A549 cell viability}

The viability of different groups of cells under various doses of $\gamma$-ray radiation was dected by the MTT assay. The cell viability at $0,2,4,6$ and 8 Gy showed no apparent difference among the miR-21-5p NC, miR-21-5p inhibitor + sihMSH2 and control groups (all $P>0.05$ ). The cell viability of the miR-21-5p inhibitor group under $\gamma$-ray radiation at $0,2,4,6$ and 8 Gy was significantly decreased compared with that of the control group (all $P<0.05$ ), whereas largely increased in the miR-21-5p mimic and sihMSH2 groups (all $P<0.05$ ). Decreased cell viability at both 6 and 8 Gy was found in comparison with those at 0,2 and 4 Gy (all $P<0.05$ ). Compared with 6 Gy, cell viability in every group at 8 Gy was also notably decreased (all $P<$ 0.05 ). The results suggest that NSCLC radiation sensitivity can be enhanced by the effect of miR-21-5p on cell viability (Fig. 4, Table 3 ).

\section{KARGER}


Table 4. Effect of miR-21-5p on cell apoptosis in A549 cells of each group under different doses of $\Gamma$-ray irradiation, *, P $<0.05$, compared with the control group, ", P $<0.05$, compared with $0 \mathrm{~Gy}, 2$ Gy and 4 Gy, $\triangle \mathrm{P}<0.05$, compared with 6 Gy; miR-21-5p, microRNA-21-5p; NC, negative control; hMSH2, human MutS homolog 2

\begin{tabular}{lccccc}
\hline Group & $0 \mathrm{~Gy}$ & $2 \mathrm{~Gy}$ & $4 \mathrm{~Gy}$ & $6 \mathrm{~Gy}$ & $8 \mathrm{~Gy}$ \\
\hline Control group & $0.14 \pm 0.07$ & $0.15 \pm 0.03$ & $0.17 \pm 0.05$ & $0.24 \pm 0.06^{\#}$ & $0.33 \pm 0.12^{\# \mathbf{\Delta}}$ \\
miR-21-5p NC group & $0.07 \pm 0.02$ & $0.12 \pm 0.05$ & $0.14 \pm 0.04$ & $0.23 \pm 0.08^{\#}$ & $0.32 \pm 0.09^{\# \mathbf{\Lambda}}$ \\
miR-21-5p inhibitor group & $0.23 \pm 0.07^{*}$ & $0.24 \pm 0.07^{*}$ & $0.25 \pm 0.07^{*}$ & $0.33 \pm 0.11^{* \#}$ & $0.47 \pm 0.13^{*}$ \\
miR-21-5p mimics group & $0.04 \pm 0.01^{*}$ & $0.06 \pm 0.01^{*}$ & $0.09 \pm 0.02^{*}$ & $0.15 \pm 0.04^{* \#}$ & $0.23 \pm 0.0$ \\
sihMSH2 group & $0.05 \pm 0.02^{*}$ & $0.06 \pm 0.01^{*}$ & $0.07 \pm 0.01^{*}$ & $0.15 \pm 0.03^{* \#}$ & $4 \pm 0.0$ \\
miR-21-5pinhibitor + sihMSH2 group & $0.06 \pm 0.03$ & $0.10 \pm 0.04$ & $0.12 \pm 0.04$ & $0.21 \pm 0.09^{\#}$ & $.3^{7}+0.1$ \\
hMSH2 overexpression group & $0.23 \pm 0.07^{*}$ & $0.24 \pm 0.07^{*}$ & $0.25 \pm 0.07^{*}$ & $0.33 \pm 0.11^{* \#}$ & 0 . \\
\hline
\end{tabular}

Fig. 6. Histogram showing apoptosis rate in each group under different doses of $\gamma$-ray radiation, as detected by flow cytometry.

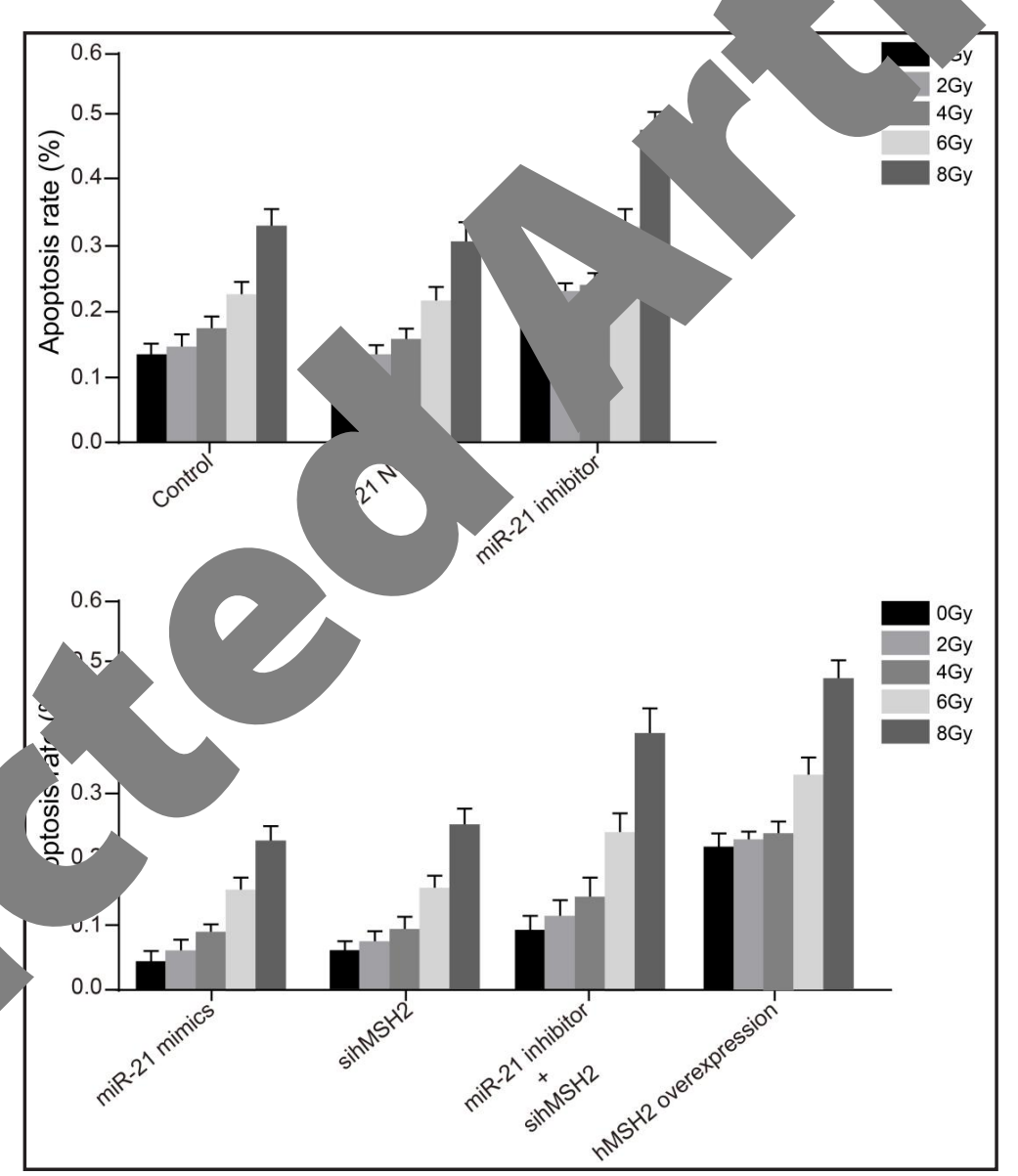

$5 p$ inhibits $A 549$ cell apoptosis

Flow cytometry was used to detect apoptosis in cells of each group under different doses of ay radiation. No apparent difference in apoptosis under $\gamma$-ray radiation at $0,2,4,6$ and was found for the miR-21-5p NC and miR-21-5p inhibitor + sihMSH2 groups compared with the control groups (all $P>0.05$ ). However, at 2, 4, 6 and 8 Gy, apoptosis in the miR-21-5p inhibitor group was significantly enhanced compared with that in the control group (all $P<$ 0.05 ), though that in the miR-21-5p mimic and sihMSH2 groups was markedly decreased (all $P<0.05)$. Comparison of different doses of $\gamma$-ray radiation showed significantly increased apoptosis in each group at 6 and 8 Gy compared with that at 0,2 and 4 Gy (all $P<0.05$ ). Relative to $6 \mathrm{~Gy}$, apoptosis was markedly increased at 8 Gy (all $P<0.05$ ). The above results indicate that miR-21-5p enhanced the radiation sensitivity of NSCLC through its effect on apoptosis (Fig. 5 and 6, Table 4).

\section{KARGER}




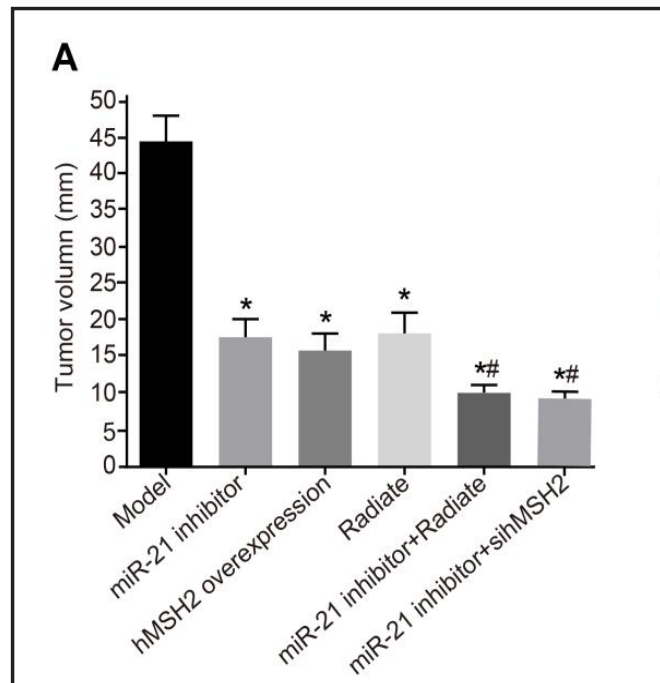

B

Fig. 7. Tumor volume and tumor weight in nude mice in each grou nude mice in each group; ${ }^{*}, \mathrm{P}<0.05$, compared with the model group group; $\mathrm{B}$, Comparison of the tumor weight of nude mice in each group group; \#, $\mathrm{P}<0.05$, compared with the radiation group $-21-5 \mathrm{p}$, micr lung cancer.

Comparison of tumor volume and tumor $\mathrm{n}$

Tumor volume and tumor weight of NSCL lower tumor volume and tumor we overexpression, miR-21-5p inhibitor groups compared with the $m^{\wedge} d e^{\wedge}$ grc in tumor volume and tumor with the radiation group $(P>$ and hMSH2 overexpress radi roup were both decreased (all $P<0.05$ ). The above we $a$ in the miR-21-5p inhibitor group compared wile those in the miR-21-5p inhibitor + radiation group mouse model (Fig. 7).

\section{ht in mice}

re measured. The results indicated $-21-5 p$ inhibitor, radiation, hMSH2
hMSH2 overexpression + radiation r cion and hMSH2 overexpression + radiation all 0.05 ). However, no significant differences roup

\section{hMSH2 ex ss vude mice}

The level of $\delta \mathrm{H}$ pression in each group was detected by immunohistochemistry. The staini sco he model, miR-21-5p inhibitor, hMSH2 overexpression, radiation, miR-21 hibitor- radiation and hMSH2 overexpression + radiation groups were $1.12 \pm$ $76 \quad 1,3.58 \pm 0.11,3.82 \pm 0.25,5.63 \pm 0.29$ and $5.48 \pm 0.16$, respectively. For the

1-5p in itor, hMSH2 overexpression, radiation, miR-21-5p inhibitor + radiation and h. expression + radiation groups, positive hMSH2 staining in the nucleus appeared sh-yellow color. Only a small number of positive cells were in the model group. mpared with the model group, the level of hMSH2 protein was notably increased in the m. 21-5p inhibitor, radiation, hMSH2 overexpression, miR-21-5p inhibitor + radiation and $\checkmark \mathrm{H} 2$ overexpression + radiation groups (all $P<0.05$ ). In contrast, compared with the radiation group, no obvious difference in the level of hMSH2 protein was observed in the miR-21-5p inhibitor group $(P>0.05)$, whereas that in the miR-21-5p inhibitor + radiation and hMSH2 overexpression + radiation groups was significantly increased $(P<0.05)$ (Fig. 8).

\section{Discussion}

It is reported that more than $50 \%$ of cancer patients receive radiotherapy during their treatment course, and radioresistance remains a major problem in the treatment of 
Fig. 8. Effect of miR-21$5 \mathrm{p}$ on hMSH2 expression levels in nude mice of each group, as detected by immunohistochemistry $(\times$ 200). A, results of immunohistochemistry in each group (× 200). Red arrow, positive expression level of hMSH2 (brownish-yellow staining). B, evaluation of hMSH2 expression level in each group by immunohistochemistry; * $\quad \mathrm{P}<0.05, \quad$ compared with the model group; \#, $\mathrm{P}<0.05$, compared with the radiation group.

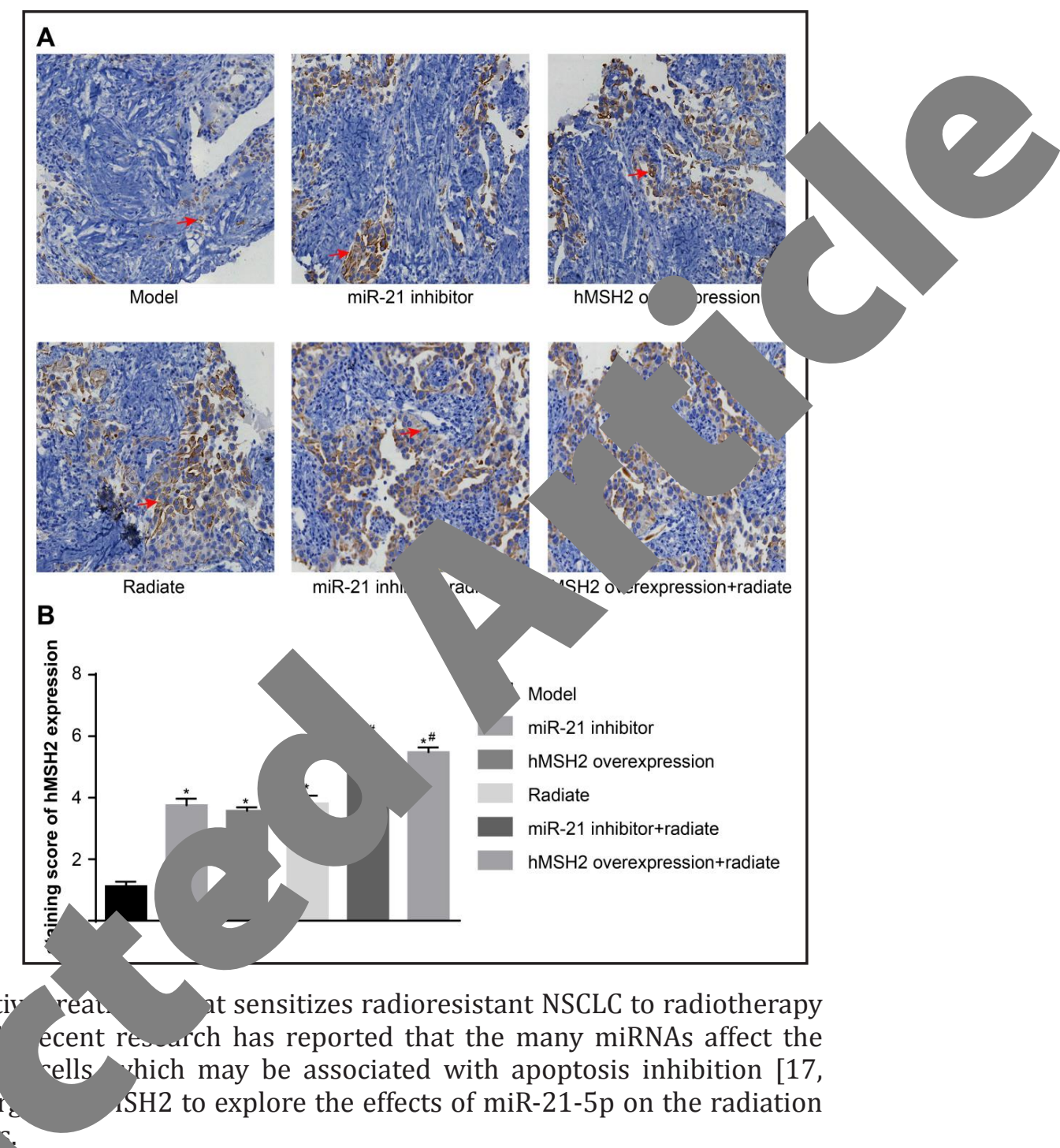

NSCLC [19]. Thus, effecti is urgently needed $[137$ radiosensitivity of NSC 20]. In this study tar sensitivity of $\mathrm{N}$

Accordin 1 ts, miR-21-5p expression was significantly decreased and the mRNA an rot a. patient pare $n$ radiation-insensitive patients. These findings suggest that miR-215 and might play roles in the radiation sensitivity of NSCLC and that inhibition of 1-5p promote the radiation sensitivity of NSCLC through hMSH2. hMSH2 is an ane the dysfunction of which may cause malignant transformation of tumor cells 21]. with our results, Zhong Z reported that miR-21-5p is a key regulator of hMSH2 moaulates the cell cycle and viability by targeting hMSH2 in human lung cancer [16]. ad ionally, Chao et al. demonstrated that miR-21-5p might mediate the resistance of slastoma cells against radiation via its target genes PDCD4 and hMSH2 and that miR1-5p and its target genes may be used for clinical radiotherapy sensitization in the future [22]. Additionally, Valeri et al. revealed that miR-21-5p induces resistance to 5-fluorouracil by down-regulating hMSH2 [23].

Furthermore, our findings suggest that miR-21-5p enhances the radiation sensitivity of NSCLC through its effect on cell viability and apoptosis. Research conducted by Zhu et al. indicated that down-regulation of miR-21 suppresses the viability of radioresistant cells and promotes elevated radiation sensitivity in CNE-2-1 cells [24]. Previous studies have indicated that changes in cytochrome c oxidase (COX) activity induce apoptosis $[25,26]$. In addition, Guo et al. demonstrated that enhanced COX activity inhibits cell apoptosis and inhibition KARGER 
of miRNA-21 suppresses NSCLC cell viability by promoting cell apoptosis via the decrease of COX-19 expression [27]. For further verification, we established an NSCLC nude mouse model and evaluated tumor volume and tumor weight as well as hMSH2 protein expression by immunohistochemistry. Compared with the model group, the tumor volume and tumor weight in the miR-21-5p inhibitor, radiation and miR-21-5p inhibitor + radiation groups we reduced; moreover, compared with the radiation group, the tumor volume and tumor weigh in the miR-21-5p inhibitor + group were smaller, suggesting that miR-21-5p expression can improve radiation sensitivity in the NSCLC nude mouse model. Additionally, we found ${ }^{\circ}$ compared with the model group, the protein expression of hMSH2 was notably increas the miR-21-5p inhibitor, radiation and miR-21-5p inhibitor + radiation group Lypres of hMSH2 protein in the miR-21-5p inhibitor + radiation group was increased s compared with the radiation group, suggesting that miR-21-5p perhaps sensitivity by down-regulating hMSH2.

Additionally, our results demonstrated an effect of radiation and $\mathrm{mi}$ previous study reported that beneficial effects of crizotinib on ALK-posi^i in combination with radiotherapy [28]. miRNAs play a critical role NSCLC and are considered as potential biomarkers for NSC development of SCLC and are considerapy [29, 30]. Overexpression of miR-124, miR-148a, miR-3619-5p an wes the growth, proliferation, metastasis and invasion of NSCLC cells [31-3 Mo ne previous study indicated that miR-21 can stimulate growth and invasion in $\quad 34$ Anastasov et al. also observed that miR-21 knockdown promotes ap sis induced adiation, with the viability of radiation-resistant cells being nearly the sam at of sens cells [35]. Another study also reported that inhibition of miR-21 signific? ances the radiosensitivity of NSCLC [36]. According to our results, miR-21-5p en cea vadiation sensitivity of NSCLC by
promoting cell viability and inhibiting apopto

\section{Conclusion}

In summary, our study

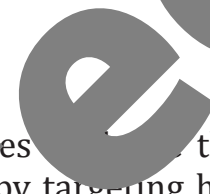
the radiation sensitivity of $\mathrm{N}$ expression, which leads to pre by tar target for clinically en limitations in this study arrest, and the eyont $\mathrm{m}$ cing th pos ble that miR-21 regulates other genes related to cell cycle by which miR-21-5p mediates radiation sensitivity in NSCLC remains Thus, iurther studies should be performed to rule out the influence of other targe en $\quad$-21-5p and to clarify the specific mechanisms by which miR-21$5 p$ mediat radi in wSitivity in NSCLC by targeting hMSH2.

\section{Disclosure Statement}

The authors have declared that no competing interests exist.

\section{References}

1 Lin L, Tu HB, Wu L, Liu M, Jiang GN: MicroRNA-21 Regulates Non-Small Cell Lung Cancer Cell Invasion and Chemo-Sensitivity through SMAD7. Cell Physiol Biochem 2016;38:2152-2162. 


\section{Cellular Physiology \begin{tabular}{l|l|l} 
and Biochemistry $10.1159 / 000481839$ & $\begin{array}{l}\text { C) } 2017 \text { The Author(s). Published by S. Karger AG, Basel } \\
\text { www.karger.com/cpb }\end{array}$ \\
\hline
\end{tabular}}

2 Jiang LP, Zhu ZT, He CY: Effects of CYP3A5 genetic polymorphism and smoking on the prognosis of non-smallcell lung cancer. Onco Targets Ther 2016;9:1461-1469.

- 3 Dedong C, Huilin X, Anbing H, Ximing X, Wei G: The Effect of ShenQi FuZheng Injection in Combination with Chemotherapy versus Chemotherapy Alone on the Improvement of Efficacy and Immune Function in Patients with Advanced Non-Small Cell Lung Cancer: A Meta-Analysis. PLoS One 2016;11:e0152270.

4 Zhu X, Fu C, Zhang L, Xu G, Wang S: MiRNAs associated polymorphisms in the 3'UTR of MET promote the risk of non-small cell lung cancer. Cell Physiol Biochem 2015;37:1159-1167. Gu X, Sun S, Gao XS, Xiong W, Qin S, Qi X, Ma M, Li X, Zhou D, Wang W, Yu H: Prognostic value of platelf lymphocyte ratio in non-small cell lung cancer: evidence from 3, 430 patients. Sci Rep 2016•6.23893. Wang Y, Peng X, Zhu L, Hu L, Song Y: Genetic variants of CHRNA5-A3 and CHRNB3-A6 p patients with advanced non-small cell lung cancer. Oncotarget 2016;10.18632/oncotarget.851 Wang J, Ji Z, Wang X, Liang J, Hui Z, Lv J, Zhou Z, Yin W, Wang L: Radical thoracic radic favorable outcomes for stage IV non-small cell lung cancer. Thorac Cancer 2016;7:18 He Z, Xia Y, Pan C, Ma T, Liu B, Wang J, Chen L, Chen Y: Up-Regulation of MiR-452 Inb b Small Cell Lung Cancer by Regulating BMI1. Cell Physiol Biochem 2015;37:387-39 Huang C, Ma R, Yue J, Li N, Li Z, Qi D: MiR-497 Suppresses YAP1 and Inhibits Tu. Cell Lung Cancer. Cell Physiol Biochem 2015;37:342-352. Yan A, Yang C, Chen Z, Li C, Cai L: MiR-761 Promotes Progression Cancer by Targeting ING4 and TIMP2. Cell Physiol Biochem 2015;

11 Deng W, Yan M, Yu T, Ge H, Lin H, Li J, Liu Y, Geng Q, Zhu M, Liu L, He analysis of the metastasis-inhibitory mechanism of 193a-3p in n Biochem 2015;35:1677-1688.

-12 Xu LF, Wu ZP, Chen Y, Zhu QS, Hamidi S, Navab R: Mi invasion, migration, and apoptosis by targeting PT City, China. PLoS One 2014;9:e103698. Ma Y, Xia H, Liu Y, Li M: Silencing miR-21 se through inhibition of PI3K/Akt. Biomed Jascur T, Boland CR: Structure and funct Int J Cancer 2006;119:2030-2

$>15$ Kouso H, Yoshino I, Miura N, mismatch repair proteins, $\mathrm{Lm}_{\mathrm{L}}$, J Surg Oncol 2008;98:37

-16 Zhong Z, Dong Z, Yang down-regulating hMSH 2 ng Z: iR-21 induces cell cycle at S phase and modulates cell proliferation by ra T, Ontum 1, Yohena T, Osoegawa A, Shoji F, Maehara Y: Expression of non-small cell lung cancer tissues and its clinical significance. all cell lung cancer. Cell Physiol 21 (miR-21) regulates cellular proliferation, Bcl-2 in lung squamous carcinoma, Gejiu

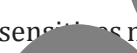
11 lung cancer A549 cells to ionizing radiation ce ponents of the human DNA mismatch repair system.

17 Wang XC, Du Expression af miRNA in postoperative radiotherapy sensitive and resistant patients of nonsmall c lung er Cancer 2011;72:92-99.

18 Shir a HJ, L Lee SJ, Seo SK, Jin HO, Park IC, Jin YW, An S: Alteration of miRNA profiles by ionizing radı. A549 human non-small cell lung cancer cells. Int J Oncol 2009;35:81-86.

ng K, Y, Hu X, Ding Y, Gong R, Liu L: Nimotuzumab enhances radiation sensitivity of NSCLC H292

's in vits sy blocking epidermal growth factor receptor nuclear translocation and inhibiting radiationNA damage repair. Onco Targets Ther 2015;8:809-818.

Oh Ju, Kim JJ, Byun JY, Kim IA: Lin28-let7 modulates radiosensitivity of human cancer cells with activation K-Ras. Int J Radiat Oncol Biol Phys 2010;76:5-8.

Vageli DP, Giannopoulos S, Doukas SG, Kalaitzis C, Giannakopoulos S, Giatromanolaki A, Koukoulis GK, Touloupidis S: Mismatch repair hMSH2, hMLH1, hMSH6 and hPMS2 mRNA expression profiles in precancerous and cancerous urothelium. Oncol Lett 2013;5:283-294.

Chao TF, Xiong HH, Liu W, Chen Y, Zhang JX: MiR-21 mediates the radiation resistance of glioblastoma cells by regulating PDCD4 and hMSH2. J Huazhong Univ Sci Technolog Med Sci 2013;33:525-529.

23 Valeri N, Gasparini P, Braconi C, Paone A, Lovat F, Fabbri M, Sumani KM, Alder H, Amadori D, Patel T, Nuovo GJ, Fishel R, Croce CM: MicroRNA-21 induces resistance to 5-fluorouracil by down-regulating human DNA MutS homolog 2 (hMSH2). Proc Natl Acad Sci U S A 2010;107:21098-21103.

24 Zhu H, Zhu X, Cheng G, Zhou M, Lou W: Downregulation of microRNA-21 enhances radiosensitivity in nasopharyngeal carcinoma. Exp Ther Med 2015;9:2185-2189. 


\section{Cellular Physiology and Biochemistry \\ Cell Physiol Biochem 2017;43:1258-1272 \\ \begin{tabular}{l|l}
\hline DOI: 10.1159/000481839 & (c) 2017 The Author(s). Published by S. Karger AG, Basel
\end{tabular}}

Song et al.: Mir-21-5p and Radiation Sensitivity in NSCLC

25 Leadsham JE, Sanders G, Giannaki S, Bastow EL, Hutton R, Naeimi WR, Breitenbach M, Gourlay CW: Loss of cytochrome c oxidase promotes RAS-dependent ROS production from the ER resident NADPH oxidase, Yno1p, in yeast. Cell Metab 2013;18:279-286.

-26 Srinivasan S, Avadhani NG: Cytochrome c oxidase dysfunction in oxidative stress. Free Radic Biol Med 2012;53:1252-1263.

27 Guo Q Zhang H, Zhang L, He Y, Weng S, Dong Z, Wang J, Zhang P, Nao R: MicroRNA-21 regulates non-small c lung cancer cell proliferation by affecting cell apoptosis via COX-19. Int J Clin Exp Med 2015;8:8835-8841.

-28 Dai Y, Wei Q Schwager C, Moustafa M, Zhou C, Lipson KE, Weichert W, Debus J, Abdollahi A: Synergistic effects of crizotinib and radiotherapy in experimental EML4-ALK fusion positive lung cancer Radiothe Oncol 2015;114:173-181.

29 Wang ZX, Bian HB, Wang JR, Cheng ZX, Wang KM, De W: Prognostic significance of serum miRP expression in human non-small cell lung cancer. J Surg Oncol 2011;104:847-851.

-30 Ma N, Zhang W, Qiao C, Luo H, Zhang X, Liu D, Zang S, Zhang L, Bai J: The Tumor Supp 509-5p by Targeting FOXM1 in Non-Small Cell Lung Cancer. Cell Physiol Biochem 2040

31 Ma T, Zhao Y, Wei K, Yao G, Pan C, Liu B, Xia Y, He Z, Qi X, Li Z, Wang J, Shao Y: Micro a Tumor Suppressor by Regulating CDH2 and Epithelial-Mesenchymal Transit Cancer. Cell Physiol Biochem 2016;38:1563-1574.

32 Li J, Yu T, Cao J, Liu L, Liu Y, Kong HW, Zhu MX, Lin HC, Chu DD, Yå Invasion and Metastasis of Human Non-Small-Cell Lung Cancer. Ce

33 Niu X, Liu S, Jia L, Chen J: Role of MiR-3619-5p in beta-Catenin-Medi. Growth and Invasion. Cell Physiol Biochem 2015;37 7-1536.

-34 Zhang JG, Wang JJ, Zhao F, Liu Q, Jiang K, Yang GH: MA 4-21 (miR-2 presses tumor suppressor PTEN and promotes growth and invasion in non-small. cancer (NSCLC). Clin Chim Acta 2010;411:846-852.

-35 Anastasov N, Hofig I, Vasconcellos IG, Rappl K, Bras Radiation resistance due to high expression iRRadiat Oncol 2012;7:206.

36 Liu ZL, Wang H, Liu J, Wang ZX: MicroRN chemo- or radioresistance in 2013;372:35-45.

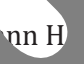
ga N, Auer G, Aubele M, Atkinson MJ: $M$ checkpoint arrest in breast cancer cells.

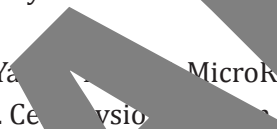
2015;37:1847-1856. expression promotes growth, metastasis, and r cells by targeting PTEN. Mol Cell Biochem 